\title{
HUKUM KELUARGA ISLAM DALAM PERSPEKTIF HAM UNIVERSAL (UDHR) DAN HAM ISLAM (UIDHR)
}

\author{
Muhammad Faisal Hamdani \\ Sekolah Pascasarjana UIN Sumatera Utara Medan \\ Jalan Williem Iskandar Pasar V, Medan Estate, Medan, Sumatera Utara 20371 \\ E-mail: fai.ham74@gmail.com
}

\begin{abstract}
Islamic Family Law in the Perspective of Universal Declaration Human Rights (UDHR) and the Universal Islamic Declaration Human Rights (UIDHR). Human Rights contain provisions relating to Islamic law, especially family law. As a Sharia scholar, this topic is crucial to observe. This paper analyzes several aspects of family law in human rights, both universal human rights and universal human rights, such as marriage, inheritance, and child custody. There are the similarities and differences in both of these human rights like in the case of marriage. In Universal Declaration Human Rights, marriage is permissible for a couple without consideration of religion at all (article 2), whereas in Universal Declaration Human Rights, there is strong indication (Article 19 (1)a) that interreligious marriage is forbidden, such as the comments of Elizabeth Mayer and others.
\end{abstract}

Keywords: UDHR, UIDHR, marriage, inheritance, hadhânah, differences, similarities, sharia

\begin{abstract}
Abstrak. Hukum Keluarga Islam dalam Perspektif HAM Universal (UDHR) dan HAM Islam (UIDHR). HAM berisi pasal-pasal berkaitan dengan hukum Islam, khususnya tentang hukum keluarga. Sebagai sarjana Syariah tentu saja hal ini punya daya tarik tersendiri untuk dikaji dan dianalisis. Tulisan ini menganalisis beberapa aspek hukum keluarga yang terdapat di dalam HAM, baik HAM Universal maupun HAM Islam seperti nikah, waris dan hadanah. Di dalam kedua HAM ini terdapat persamaan dan perbedaan seperti dalam hal nikah. Dalam UDHR (HAM Universal/Barat) nikah dibolehkan bagi pasangan suami (calon mempelai) tanpa pertimbangan agama sama sekali (pasal 2), sedangkan di dalam UIDHR (HAM Islam) terdapat indikasi kuat (pasal 19 ayat [1a]) bahwa perbedaan agama terlarang dalam pernikahan, seperti komentar Elizabet Mayer dan lainnya.
\end{abstract}

Kata kunci: UDHR, UIDHR, nikah, waris, hadanah, perbedaan, persamaan, syariah

\section{Pendahuluan}

Diskurus Hak Asasi Manusia (HAM) selalu menjadi pembicaraan hangat di pelbagai kalangan. Sayangnya, masyarakat Muslim Indonesia, bahkan mungkin sebagian besar civitas academika tidak mengenal HAM Islam atau UIDHR (Universal Islamic Declaration of Human Right) yang punya titik perbedaan dengan HAM Universal/ Internasional atau UDHR (Universal Declaration of Human Right). Uniknya lagi, Komnas HAM di Indonesia seolah-oleh tidak pernah menyentuh istilah HAM Islam meskipun anggotanya Muslim. Mereka hanya berpedoman pada HAM Internasional (UDHR). Jika HAM Internasional bersifat lebih universal tanpa dibatasi agama, HAM Islam sesuai dengan namanya, berlabel Islam yang isinya disesuaikan dengan Syariat Islam (Hukum Islam itu sendiri).

Naskah diterima: 10 Agustus 2015, direvisi: 25 Agustus 2015, disetujui untuk terbit: 3 November 2015.
Dalam hal ini, penulis menganalisis segi-segi Hukum Keluarga yang terdapat dalam HAM Internasional dan HAM Islam untuk melihat persamaan dan perbedaannya. Studi ini dilakukan dengan membaca seluruh pasal yang ada dalam HAM Internasional dan HAM Islam serta menganalisisnya dengan kajian hukum Islam itu sendiri (syariat). Beberapa pendapat tokoh tentang persamaan dan perbedaan HAM Internasional dan HAM Islam ini juga dikutip sebagai bahan penguat.

Studi diharapkan dapat memberikan sedikit sumbangan cakrawala akademik dalam rangka melihat sisi-sisi positif HAM Internasionnal dengan membandingkan dengan HAM Islam sekaligus titik perbedaannya dalam aplikasi kehidupan masyarakat Muslim, khususnya di Indonesia serta kelebihan HAM Islam di sisi yang lain.

Seorang Muslim terkadang lebih mengedepankan pasal-pasal HAM Universal daripada HAM Islam itu sendiri dan bahkan lebih tidak logis lagi 
mendahulukannya dari UUD 1945, dasar Negara Pancasila, dan UU yang berlaku di suatu negara yang sejatinya merupakan batasan yang tidak boleh ditinggalkan masyarakat setempat.

Mungkinkah kita mendahulukan HAM Internasional daripada aturan yang berlaku di negara kita dalam aplikasi kehidupan sehari-hari? Artikel singkat ini hanya pengantar bagi kajian besar lainnya yang sampai hari ini belum teraplikasikan dengan baik.

\section{HAM dan Syariat Islam}

Jika kita melihat langsung pasal-pasal yang ada dalam UDHR maka kita akan menemukan banyaknya gagasan besar yang berkenaan dengan demokrasi dan HAM yang selaras dengan pemikiran Islam. ${ }^{1}$ Sebenarnya, sejak Islam muncul, Nabi Muhammad Saw. telah menyerukan pada seluruh manusia bahwa mereka adalah umat yang satu, turunan Adam yang tidak dibedakan oleh ras, suku bansa, bangsa, kekayaan, dan jenis kelaminnya.

Pada awal Islam hadir, dalam tradisi masyarakat Arab terjadi inequality (perbedaan yang menyebabkan diskriminasi) dalam segala bidang. Sistem kehidupan kaum Quraish berdasarkan kesukuan yang memunculnya perbudakan, diskriminasi sosial dan jenis kelamin laki-laki dan perempuan. Orang Arab juga cenderung menganggap mereka memiliki kelebihan dibanding orang-orang nonArab baik dari segi inteligen (kecerdasan), literatur (naskahnaskah), agama, dan warisan kebudayaan leluhur mereka. ${ }^{2}$ Nabi Muhammad Saw. hadir untuk menyerukan persamaan derajat dan mengatakan tidak ada kelebihan orang Arab dengan non-Arab seperti yang disampaikan dalam khotbah haji wada beliau. ${ }^{3}$

Akan tetapi, menurut Sukron Kamil dkk., masih sering terjadi ambiguitas di dunia Islam antara klaim dan praktik antara doktrin HAM Islam yang lebih lengkap daripada doktrin HAM Internasional seperti pengusiran Nashr Hamid Abu Zaid (Mesir), Fazlur Rahman (Pakistan), Abdullah Ahmad an-Naim (Sudan), Abdul Karim Soroush(Iran), dan bahkan Mahmod Thaha dihukum gantung oleh Rezim yang berkuasa (di Sudan). ${ }^{4}$

${ }^{1}$ Candra Muzaffar, Hak Asasi Manusia dalam Tata Dunia Baru, diterjemahkan oleh Poerwanto (Bandung: Mizan,1995), h. 58.

${ }^{2}$ Parveen Shaukat, Human Rights In Islam, (India: Adam Publisher \& Distributors, 1995), h. 87.

3 Syaukat Hussein, Hak Asasi Manusia Dalam Islam, (Jakarta: Gema Insani Press, 1996), h. 86.

${ }^{4}$ Sukron Kamil dkk., Syariah Islam dan HAM (Jakarta : CSRC, 2007), Cet I, h. 31.
Tahir Mahmud berpendapat ada beberapa aspek hak-hak asasi manusia yang dikembangkan Islam sejak awal kehadirannya. ${ }^{5}$ Pertama, hak yang sama di hadapan dan mendapatkan perlindungan hukum. Pada dasarnya, Islam tidak mengenal hak istimewa (superior) yang didasarkan pada keturunan, kebangsaan, ataupun aturan buatan lainnya yang dibentuk manusia. ${ }^{6}$ Diskriminasi manusia yang didasarkan pada nasionalnya (kebangsaan), keturunan maupun perbedaan ras bukanlah ajaran yang dianut dan dikembangkan oleh Islam. ${ }^{7}$ Alquran sendiri menegaskan:

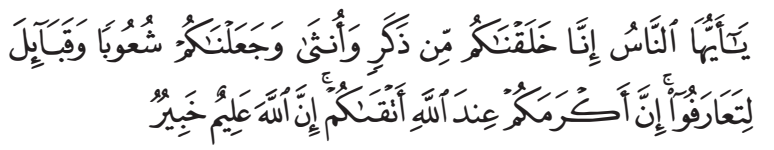

Hai sekalian manusia Kami telah menjadikan kamu dari satu bapak Adam, dan menjadikan kamu bersuku-suku dan berbangsa-bangsa (hanyalah) supaya kamu saling mengenal. Sesungguhnya yang paling mulia di antara kamu di sisi Allah adalah yang paling takwa. ${ }^{8}$

Di sisi lain Islam (Alquran) tidak membedakan antara si miskin dan si kaya dihadapan hukum. Nabi sendiri melarang keras deikriminasi yang dilakukan oleh seorang berdasarkan keturunannya dengan memberi contoh pada keluarga beliau sendiri. Nabi dengan tegas mengatakan, andai saja Fatimah binti Muhammad melakukan pencurian pasti akan diberi hukuman yang sama (dipotong tangannya). Perbedaan yang dasar antara seseorang dengan yang lainnya adalah tingkat ketakwaannya, bukan kekayaan, keturunan, atau status sosialnya.

Selanjutnya sikap netral (tanpa diskriminasi) ini juga dilaksanakan para khalifah selanjutnya. Khalifah Abu Bakar, misalnya, menghilangkan diskriminasi antara si kaya dan si miskin dengan memandang semua sama dihadapan hukum baik rakyat biasa maupun penguasa. Demikian juga Umar al-Faruq, khalifah kedua, menolak memberikan status khusus pada tuan tanah Suriah, Jabal Ghassani. Bahkan dirinya harus disamakan dihadapan hukum dengan masyarakat biasa lainnya. Demikian juga Ali, memiliki kedudukan yang sama di depan hukum bahkan dikalahkan dalam peradilan melawan seorang

\footnotetext{
${ }^{5}$ Tahir Mahmud, Human Rights in Islamic Law, Edit. 1 (New Delhi: Institute of Objective Studies, 1993), h. 34

${ }^{6}$ Syaukat Hussein, Hak Asasi Manusia dalam Islam, h. 86.

Parveen Syaukat berpendapat bahwa salah satu aspek Islam terpenting yang mampu mendobrak diskriminasi ini adalah kosep Mahakuasa-Nya yang mendobrak seluruh rintangan atau sikap-sikap yang immoral. Persamaan derajat ini juga tampak dalam pelaksanaan ibadah haji yang menuntut ketundukan semua orang kepada Allah Swt. tanpa membeda-bedakan ras, suku bangsa, bangsa. Parveen Syaukat, Human Righth in Islam, h. 87-88.

${ }^{8}$ Qs. Al- $\underline{\text { Hujarât: }}$ 13, demikian juga Qs. 4. al-Nisầ ayat 1, yang menyatakan manusia diciptakan dari Adam (satu bapak) dan kemudian berkembang menjadi laki-laki dan perempuan yang banyak.
} 
Kristen Dzimmi pada kasus baju perang. ${ }^{9}$

Dengan demikian, menurut Tahir Mahmood, Islam tidak mengenal sistem kasta seperti yang terdapat pada negara India misalnya. Menurutnya, Konsep kasta ini adalah konsep yang asing dalam Islam. Islam hanya mengenal konsep kesamaan derajat. Dalam negara Islam, tidak ada hak-hak istimewa yang diberlakukan pada orang-orang yang superior melebihi masyarakat biasa.

Kedua, hak kebebasan memilih agama. Islam juga memberikan kebebasan pada setiap orang untuk memeluk agama sesuai dengan keinginannya. Alquran menyatakan: (a) "Tidak ada paksaan dalam hal (pemilihan) agama (Q.s.al-Baqarah: 256); "Katakanlah hai Nabi! Hai orang-orang yang non-Muslim aku tidak akan menyembah apa yang kamu sembah dan kamu tidak akan menyembah apa yang aku sembah..., bagimu agamamu dan bagiku agamaku.(Q.s. al-Kafirûn ayat 1 -6).”

Dengan demikian, kata Thahir, dalam Islam tidak ada paksaan. Memang umat Islam disuruh mengajak orang-orang non-Muslim masuk ke dalam Islam tetapi bukan dengan pemaksaan. Nabi sendiri ketika dilempari masyarakat kota Thaif beliau hanya berkata, "Saya hanya bisa mengajak kamu kepada kebenaran yang hakiki, jika kamu enggan maka tinggalkanlah.” Sikap Nabi ini juga diikuti para sahabat lainnya. Setelah melakukan penaklukan terhadap kota-kota (negara-negara) yang ada, kemudian mereka diberikan dua pilihan masuk Islam atau membayar jizyah, sebagai biaya bagi negara melindungi seluruh hak mereka sehingga hidup damai dalam negara Islam.

Orang-orang dzimmî juga diberi kehormatan (dihormati) baik dalam kehidupan sosial maupun politik seperti yang tercermin dalam sikap Rasul dan para sahabat lainnya. Selama masa nabi Saw. sekelompok pengikut agama Hindu dan Budha seperti Kaum Arab Budha (Ahamira), Jats (Zuts) dan Thakurs (Takakira) dibiarkan hidup damai dan tidak pernah dipaksa memasuki Islam. Mereka sangat dihormati nabi dan bahkan mereka juga sangat menghormati nabi. ${ }^{10}$

Ketiga, hak untuk hidup dan memperoleh kebutuhankebutuhannya. Menurut Thahir, jiwa manusia dianggap satu hal yang suci dalam Islam sampai-sampai Allah mengatakan, "Janganlah kamu membunuh jiwa yang diharamkan Allah, kecuali dengan hak (hukum menentukan demikian)" 11 Dalam hal ini, nabi saw. juga memberikan pernyataan yang sama. Beliau bersabda,

\footnotetext{
9 Disarikan dari Tahir Mahmud, Human Rights in Islamic Law, Edit. 1 h. 35-36

${ }^{10}$ Tahir Mahmood, Human Rights in Islamic Law, h.37.

${ }^{11}$ Q.s. al-An'am: 151 dan Q.s. Al-Isra': 33.
}

"Hai manusia jiwamu adalah haram (dibunuh) satu sama lainnya sampai hari kiamat." 12

Rekomendasi Tuhan dan nabi tersebut jelas-jelas menyatakan perlindungan terhadap jiwa seluruh manusia. Jika pada zaman Jahiliyah bayi-bayi perempuan dibunuh oleh ayahnya sendiri, maka Islam melarang keras pembunuhan itu. Bahkan nabi sendiri menyatakan bahwa orang yang mengasuh anak yatim dan mendidiknya akan bersama beliau di surga kelak.

Ketika seorang anak lahir, menurut hukum Islam, mereka mempunyai hak-hak dan kebutuhan hidup yang harus dipenuhi orang-orang yang yang paling dekat dengannya seperti orang tua dan kerabatnya. Seandainya bayi itu setelah lahir tidak memiliki orang tua maka negara bertanggung jawab terhadap kelahiran bayi itu supaya tetap hidup. Hak hidup juga merupakan hak asasi paling dasar bagi seluruh manusia yang dijamin nabi ketika khutbah haji wada nya. ${ }^{13}$

Kebutuhan-kebutuhan yang pokok lainnya juga dijamin dalam Islam. Setiap orang berhak mencari nafkah. Di samping itu, Islam memberikan subsidi pada orang-orang yang tak mampu berusaha (miskin) dengan istilah "zakat". Bahkan mencela orang-orang yang tidak punya rasa sosial terhadap lingkungannya, yang tak mau menginfakkan sebagian hartanya untuk memberi makan orang-orang yang kelaparan. Hal itu ditegaskan oleh nabi, "Tidak dibenarkan bagi orang beriman tidur dengan nyenyak sementara tetangganya merintih kelaparan."

Keempat, persamaan hak dalam mobilitas dan kebebasan dalam bicara. Menurut Tahir, jauh sebelum adanya undang-undang modern tentang hal ini, Islam telah menjamin kebebasan setiap individu untuk berbicara. Kebiasaan orang Islam pada waktu itu untuk bertanya tentang masalah-masalah berkenaan dengan perintah yang diwahyukan Tuhan sehingga Hubab bin Madhar juga pernah mengkritik nabi. Dalam perang Badar, Nabi memilih satu tempat yang pas untuk menyerang musuh, Hubab mengatakan apakah itu wahyu Tuhan? "Tidak”, jawab Nabi. Maka Hubab menunjukkan satu tempat yang menurutnya pantas dan usulnyapun diterima ${ }^{14}$.

Hukuman (penjara) tanpa berdasarkan bukti yang

\footnotetext{
${ }^{12}$ Hadis ini dikutip Tahir Mahmood pada Konferensi Pendeta tentang Keberadaan Orang-Orang Kristen di Negara-Negara Muslim, Varanasi, 26 November, 1981, First Published in Islamic and Comparative Law Quarterly, 32-44 (1984).

${ }_{13}$ Terdapat juga dalam Harun Nasution dan Bahtiar Effendi (ed.), Hak Azasi Manusia Dalam Islam (Jakarta: Yayasan Obor Indonesia, 1987), h. 65.

${ }^{14}$ Harun Nasution dan Bahtiar Effendi (ed.), Hak Azasi Manusia dalam Islam, h. 67
} 
jelas dan penculikan ilegal juga seluruhnya dilarang dalam Islam. Ada suatu peradilan pada masa nabi (di Masjid Madinah), ketika itu ada seseorang yang bertanya mengapa tetangganya dipenjarakan. Pertanyaan ini diulangi tiga kali dan polisi (sejenis polisi) yang ada ketika itu tidak dapat memberikan keterangan, maka nabi memerintahkan agar orang yang ditahan itu dilepaskan. ${ }^{15}$

Semua orang Islam berhakmengemukakan pendapatnya jika melihat suatu masalah atau tindakan yang menyimpang dari kebenaran. Abdul Wahid menyatakan orang Islam itu tidak perlu takut mengemukakan keberatannya dengan alasan yang masuk akal. Islam memberikan kesempatan yang selebar-lebarnya bagi setiap umatnya untuk mengutarakan kritik konstruktif (membangun) demi peradaban masyarakat itu sendiri ${ }^{16}$.

Kelima, hak untuk memperoleh perlakuan yang adil. Dalam hal ini Tuhan berfirman, "dan jika kamu menghukumi diantara manusia maka berikanlah putusan hukum yang adil". ${ }^{17}$ Tahir Mahmood menjelaskan ayat ini ditujukan bagi negara, khususnya instansi peradilan dan seluruh orang yang melibatkan dirinya menjadi hakim, penengah, wasit atau tempat konsultasi ${ }^{18}$. Hak untuk memperoleh keadilan juga merupakan bagian dari hak asasi manusia.

Tahir juga mengatakan bahwa dalam Islam tidak dikenal pengadilan tertutup, seluruhnya harus dibuka untuk umum, terdakwa harus dibebaskan mendengar dan diberi kesempatan untuk membela diri dan tidak boleh diberi hukuman tanpa bukti-bukti yang jelas, sehingga nabi sendiri mengatakan, "Adalah lebih baik bagi hakim bersalah karena memebebaskan seseorang dari hukuman daripada bersalah karena menghukum seseorang".

Keenam, hak untuk dihormati dan dihargai. Dalam hal ini, menurut Tahir, Alquran menjelaskan, "Hai orang-orang yang beriman janganlah sebagian kamu menganggap rendah sebagian yang lain, karena sesungguhnya orang yang dianggap rendah itu mungkin saja lebih baik dari orang yang menganggap rendah..." 19

Dengan demikian, segala bentuk penghinaan, perendahan, pengejekan, dan pemberian gelar yang buruk, finah, dan prasangka buruk dan jahat kepada

\footnotetext{
${ }^{15}$ Tahir Mahmood, Human Rights in Islamic Law, h. 41

16 Ali Abdul Wahid Wafi, Prinsip Hak Asasi dalam Islam, diterjemahkan oleh oleh Abu Ahmad Al-Wakidi (Solo: Pustaka Mantiq,1991), 98. Islam adalah agama yang tidak hanya menghendaki keimanan dan kesalehan tetapi kesadaran untuk saling menasihati dalam kebenaran dan kesabaran (Q.s.103. al-Ashr ayat 1-3).

${ }^{17}$ Q.s. 4.An-nisa': 58

${ }^{18}$ Tahir Mahmud, Human Right in Law, h. 42

${ }^{19}$ Q.s. al- Hujarât: 11-2
}

sesama manusia, khususnya kepada sesama saudara seagama tidak dibenarkan dalam Islam. Islam sangat menghargai dan melindungi harga diri manusia.

Nabi sendiri, kata Tahir, mencela orang-orang yang suka mengkhibah saudaranya. Dengan begitu, Islam juga menjadikan hak dignity dan refutasi (kehormatan diri dan nama baik) sebagai hak asasi yang selalu dijaga dan diperhatikan.

Ketujuh, hak untuk hidup berumah tangga (berkeluarga). Keluarga adalah satu unit terpenting dari kehidupan sosial. Keluargalah yang membentuk kepribadian yang kemudian diwujudkan dalam kehidupan bermasyarakat pada skala yang lebih besar dan luas. Pengaruh keluarga sangat besar dalam membentuk kepribadian seseorang di samping pengaruh lingkurang yang lebih bersifat eksternal.

Mahmud menjelaskan perkawinan adalah satu bentuk ideal dalam membentuk keluarga. Tuhan menciptakan Hawa supaya dapat menemani Adam disurga dan kemudian Tuhan menciptakan rasa cinta dan kasih sayang diantara mereka. Selanjutnya perasaan ini dimiliki oleh seluruh keturunan adam dan hawa secara turun-temurun. Perasaan ini jugalah yang memunculkan sakinah (ketenangan dan ketentraman hidup). ${ }^{20}$

Kedelapan, hak untuk berusaha dan memiliki harta. Dalam hukum keluarga Islam, setiap orang memiliki hak untuk memiliki harta pribadinya. Islam, kata Mahmud, tidak mengenal konsep di mana hak-hak anak berada ditangan ayahnya atau milik keluarganya atau milik kedua orang tuanya secara mutlak. Alquran sendiri menyatakan bahwa "seseorang akan memperoleh sesuai dengan apa yang dia usahakan"21.

Setiap orang bekerja menurut profesinya atau sesuai dengan yang dia inginkan. Tidak ada pemaksaan kerja bagi seorang buruh sekalipun. Alquran diturunkan pada masa (di zaman) adanya sistem perbudakan, maka nabi datang dengan membawa misi anti perbudakan dan menghapusnya secara perlahan (gradual, bertahap tapi pasti). Di samping itu membebaskan budak dijadikan sebagai amal saleh yang benilai tinggi dihadapan Islam. Pelanggaran-pelanggaran hukum Islam pun selalu mengaitkan hukumannya dengan membebaskan budak seperti kaffarah dzihâr, kaffarah sumpah, dan diat pembunuhan yang tidak sengaja. Bukti nyata tentang hal ini, kata Mahmud, juga dipraktikkan nabi dengan menjadikan Zayd, yang semula seorang budak sebagai

\footnotetext{
${ }^{20}$ Pernyataan ini tertera dalam Q.s. Ar-Rum ayat 21.

${ }^{21}$ Pernyataan ini terdapat pada ayat: ....

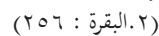


anak angkat beliau. ${ }^{22}$ Bahkan kata Maudhudi, Rasulullah sendiri telah memerdekakan 63 orang budak, sedangkan Aisyah membebaskan 67 budak dan Abbas 70 budak dan bahkan Abdullah bin Umar memerdekakan budak sebanyak 1000 orang dan Abdurrahman membeli 3000 orang budak dan kemudian memerdekakannya. Berkat hal itu, perbudakan di negeri Arab tuntas hanya dalam waktu 40 tahun. ${ }^{23}$

\section{Hukum Keluarga dalam HAM Universal (UDHR)}

HAM universal2 ${ }^{24}$, yang selanjutnya penulis sebut HAM internasional untuk tidak mengatakan HAM Islam tidak universal, terdiri dari Preamble (mukadimah) dan 30 Pasal. Salah satu tujuan HAM ini diciptakan adalah supaya orang-orang tidak melakukan pemberontakan yang dianggap jalan terakhir dalam menentang kezaliman, ketidakadilan dan penjajahan.

Pasal-pasal dalam HAM internasional selalu membicarakan masalah hak seseorang ketika dia terlahir sebagai manusia yang berbudi dan berakal ke dunia ini dengan kurang memperhatikan pada pelaksanaan kewajiban-kewajiban seseorang pada negara, dirinya, dan masyarakat sosialnya ${ }^{25}$. Pernyataan-pernyataan yang ada selalu didahului dengan kata-kata setiap orang berhak terhadap sesuatu dan seterusnya. Akan tetapi HAM internasional ini bersifat universal tanpa memandang misalnya bangsa, warna kulit, jenis kelamin, bahasa, agama, asal-usul kebangsaan (nenek moyang) atau kemasyarakatan, milik (kekayaan), ke-

${ }^{22}$ Tahir Mahmood, Human Rights in Islamic Law, h.46

${ }_{23}$ Abul A'la Maududi, Hak-Hak Asasi Manusia dalam Islam, diterjemahkan dari Human Rights In Islam oleh Bambang Iriana Djajaatmaja, (Jakarta: Bumi Aksara, 1995), I, h. 17.

${ }^{24}$ Konsep keuniversalan UDHR masih dipertanyakan oleh Antonio Cassesse karena menurut beliau ada perbedaan konsepsi filsafat Barat dan tradisi budaya negara-negara sosial dan agama ketika memandang UDHR ini. Jika Barat memandang hak-hak asasi itu tertanam dalam diri manusia dan ada sebelum adanya suatu negara sedangkan di negara-negara sosial mengatakan hak-hak asasi manusia tidak ada sebelum negara ada dan hak asasi itu diberikan oleh negara. Antonio Cassesse, Hak Asasi Manusia di Dunia yang Berubah, diterjemahkan oleh A.Rahman Zainuddin (Jakarta: Yayasan Obor Indonesia, 1994), cet I, h. 71-72.

${ }^{25}$ Masalah kewajiban seseorang hanya disentuh pada satu pasal yaitu pada pasal 29 ayat 1 di mana seseorang mempunyai kewajiban hanya terhadap masyarakat tempat dia tinggal. Peter Davis, Peter Davis, Hak-Hak Asasi Manusia: Sebuah Bunga Rampai, diterjemahkan oleh A. Rahman Zainuddin (Jakarta: Yayasan Obor Indonesia,1994) sedangkan dalam UIDHR masalah kewajiban-kewajiban disentuh dalam Preambule pasal g yang berisi 14 kewajiban, pasal I ayat 2/b, pasal IV ayat b, $c$ dan e, pasal V ayat e, pasal XII ayat b dan lain-lain. Tahir Mahmood, Human Rights in Islamic Law, h. 162-168. Bahkan uniknya, menurut Sukron Kamil dkk. dalam bukunya, Syariah Islam dan HAM, antara konsep civil liberties (kebebasan civil) dan civil rights (hak-hak sipil) walaupun dibedakan tetapi selalu dipertukarkan dalam penggunaannya. lahiran ataupun kedudukan baik dari segi kedukuan politik, misalnya berasal dari negara yang belum merdeka, jajahan seperti yang tercantum pada Pasal 2.

Setelah membaca dan menganalisis dapat penulis simpulkan bahwa pokok-pokok yang menjadi hak bagi seluruh manusia dalam UDHR adalah: (a) Hak untuk memiliki martabat (dignity: kehormatan diri, pen.), tidak dihina dan tidak diperlakukan sebagai budak seperi yang tercantum pada pasal 1, pasal 4 dan pasal 5; (b) hak untuk hidup, merdeka, dan selamat seperti pada pasal 3; (c) hak untuk mendapatkan keadilan, perlindungan hukum, tidak ditangkap tanpa bukti yang nyata dan untuk mengeluarkan pendapat (bebas dalam bicara) dan berserikat (berkumpul membentuk organisasi) seperti pada pasal 7, 8, 9,10,11,19 dan 20; (d) hak untuk bebas mengurus diri dan keluarganya sendiri tanpa intervensi pihak atau instansi lain seperti pada pasal 12; (e) hak untuk mendapatkan tempat tinggal atau hidup ditempat yang ia sukai seperti yang terdapat pada pasal 13; (f) hak untuk lari dan mencari perlindungan ke segala penjuru dunia selama dia tidak melanggar hukum-hukum dasar PBB seperti pada pasal 14; (g) hak untuk mendapatkan pengakuan sebagai warga negara dari negara yang dimiliki seperti pada pasal 15; (h) hak untuk mencari dan mendapatkan jodoh secara bebas tanpa dibatasi kebangsaan, warga negara, dan agama seperti pada pasal 16; (i) hak untuk memiliki harta (pasal 17); (j) hak bebas untuk berpikir, mengganti agama dan beribadah (Pasal 18); (k) berhak berdaulat dan ikut serta (berpartisipasi) dalam urusan negerinya sendiri seperti menduduki jabatan pemerintahan. (Pasal 21); (l) berhak tehadap jaminan sosial, berusaha, dan bekerja sesuai dengan keinginannya, mendapat upah dari pekerjaannya dan perlindungan kepentingan baik secara moral dan material (Pasal 22, 23 dan 27 ayat [2]); (m) hak untuk istirahat, liburan, menikmati seni dan berbudaya, memporoleh kesehatan dan tingkat kehidupan yang layak bagi diri dan keluarganya (Pasal 24, 25, dan 27 ayat [1]); dan (n) hak untuk mendapatkan pendidikan dan mendidik anak (Pasal 26).

Dengan melihat pasal-pasal di atas, ada beberapa aspek hukum keluarga yang disentuh oleh Deklarasi HAM (UDHR) ini. Pertama, perkawinan atau berkeluarga. Aspek ini tercantum pada pasal 16 yang menyatakan bahwa setiap orang dewasa baik pria ataupun wanita, dengan tidak dibatasi kebangsaan, warga negara dan agama berhak untuk mencari jodoh dan membentuk keluarga (ayat 1). Perkawinan yang dilakukan harus berdasarkan suka sama suka (ayat 2).

Pasal 12 dan pasal 23 ayat 3 dan 25 menyentuh tentang 
hak untuk mengatur keluarga atau rumah tangganya tanpa intervensi orang lain, memperoleh pekerjaan demi menjamin kehidupan diri dan keluarganya, dan mempunyai kehidupan yang layak untuk menjamin tersedianya kesehatan, sandang-pangan, pakaian dan perumahan bagi diri dan keluarganya.

Kedua, tentang waris. Karena tidak berdasarkan konsep Islam maka dalam masalah ini HAM Internasional tidak menyebutkannya secara jelas dan tegas, namun yang disebutkan adalah bahwa setiap orang berhak atas pemilikan harta tanpa disebut dari mana harta itu diperoleh dan dari apakah berasal di usaha sendiri atau dari harta warisan. Pemilikan harta itu juga bisa berbentuk harta pribadi atau harta bersama (Pasal 17). Ini mengindikasikan kepemilikan harta disesuaikan pada ketentuan yang berlaku di negara masing-masing warga.

Ketiga, hadanah (pemeliharaan anak). Adapun berkenaan dengan hal ini HAM Internasional menyebutkan bahwa ibu bapak, tanpa memihak salah satunya, adalah orang yang paling utama dalam memilih pendidikan anak (pasal 26 ayat 3). Anak-anak meskipun anak illegal (di luar perkawinan) harus diberikan perlindungan dan bantuan istimewa (pasal 25 ayat 1). Dalam hal ini HAM tidak menyebutkan bantuan ini diperoleh dari siapa, ayah atau masyarakat umum lainnya. Namun, dapat dipahami dari redaksi yang ada bahwa ibu dan anak mendapat perawatan, bantuan istimewa dan perlindungan sosial pertama-tama dari suami (ayahnya) dan instansi sosial yang terkait seperti rumah sakit, panti asuhan dan secara umum oleh negara.

Adapun pendidikan yang wajib diberikan kepada anak setidak-tidaknya adalah pendidikan dasar. Adapun pendidikan rendah (Kindergarden=TK misalnya) dan tingkat tinggi (universitas) tidaklah diwajibkan (pasal 26).

\section{Aspek-aspek Hukum Keluarga dalam HAM Islam (UIDHR)}

Deklarasi hak-hak asasi manusia dalam Islam dicetuskan pada 19 September 1981. HAM universal Islam ini secara garis besar terdiri dari Preamble (pendahuluan) dan 23 macam hak (pasal). Namun, HAM Islam ini tampaknya agak sedikit berbeda dengan HAM Internasional.

Sesuai dengan namanya HAM Islam (UIDHR), maka isinya selalu disandarkan pada ajaran-ajaran Islam secara universal. Seperti yang terdapat pada preamble UIDHR ini berdasarkan pada pengakuannya terhadap Alquran dan Sunah yang dianggap wahyu Tuhan yang tak dapat dikurangi (dibatasi), dihapuskan ataupun diabaikan oleh otoritas penguasa, para perwakilan rakyat dan atau institusi lainnya. ${ }^{26}$

UIDHR ini juga didasarkan pada kepercayan orang Islam secara universal terhadap Tuhan sebagai pencipta, penguasa, pembimbing seluruh manusia dan firmanNyalah yang dijadikan sumber utama dari segala sumber hukum. Tuhan juga menciptakan manusia sebagai khalifah di muka bumi dan menjadikan Muhammad adalah rasul pilihan yang membawa petunjuk bagi manusia di dalam bumi Tuhan yang luas ini, mengajak mereka kepada pesan-pesan Islam. ${ }^{27}$

Disamping itu, UIDHR ini tidak hanya berbicara sepihak, maksudnya tidak hanya berbicara tentang hakhak asasi yang harus dimiliki oleh seluruh manusia, tetapi juga berbicara tentang kewajiban-kewajiban yang harus dilaksanakan oleh manusia. Jika diurai lebih lanjut, maka HAM ini berisi tentang macam hak-hak asasi manusia sebagai berikut: (1) Hak untuk hidup (Pasal I); (2) Hak untuk bebas (merdeka) baik secara sosial, politik, ekonomi dan kebudayaan (Pasal II); (3) Hak untuk dipandang sama (sederejat) dan tidak diskriminasi baik dalam pandangan hukum, memperoleh upah dan kesempatan bekerja (Pasal III); (4) Hak untuk mendapatkan atau memperoleh keadilan, untuk diperlakukan secara adil atau diberi hukuman yang adil (Pasal IV dan V); (5) Hak untuk dilindungi dari perlakuan sewenang-wenang atau dari siksaan atau kekejaman (Pasal VI dan VII); (6) Hak untuk mendapatkan perlindungan terhadap kehormatan, nama baik dan keselamatan diri (Pasal VIII dan IX); (7) Hak-hak minoritas seperti tidak boleh dipaksa memeluk suatu agama atau menjalankan hukum sesuai dengan agamanya (Pasal X dan Pasal XII ayat (a/1) dan (e/5) dan Pasal XIII); (8) Hak dan Kewajiban untuk berpartisipasi dalam kehidupan sosial, seperti mendirikan institusi-institusi dan perwakilan-perwakilan lainnya (Pasal XIV); (9) Hak untuk memperoleh kebebasan dalam beriman, berpikir dan berbicara (Pasal XII); (10) Hak untuk berusaha (berekonomi) dan memperoleh penghidupan yang layak sesuai dengan hukum (Pasal XV); (11) Hak untuk memperoleh perlindungan terhadap harta kekayaan yang dimiliki (PasalXVI); (12) Hak untuk mendapatkan makanan, pakaian, pendidikan dan perawatan sosial bagi pekerja (Pasal XVII); (13) Hak untuk berkeluarga, mendidik anak-anaknya sesuai dengan agamanya dan tidak memaksa anak bekerja pada usia dini yang relatif masih muda (Pasal XIX); (14) Hak-hak istri (perempuan

\footnotetext{
${ }^{26}$ Tahir Mahmood, Human Rights in Islamic Law, h. 161.

${ }^{27}$ Tahir Mahmood, Human Rights in Islamic Law, h. 161.
} 
yang dinikahi) seperti memperoleh nafakah, memiliki hak khuluk dan meneriwa harta warisan dari suaminya yang meninggal, orang tuanya, anaknya, dst. (Pasal XX); (15) Hak untuk memperoleh pendidikan (Pasal XXI); (16) Hak untuk mendapatkan perlindungan kebebasan diri sendiri (privacy) (Pasal XXII); (17) Hak untuk pindah dan bertempat tinggal di mana saja yang dia sukai (pasal XXIII) ${ }^{28}$.

Dengan demikian, setelah melihat pasal-pasal tersebut, ternyata aspek-aspek hukum keluarga yang disoroti UIDHR juga tidak seluruhnya. Aspek-aspek itu adalah: Pertama, aspek nikah dan cerai (dalam bentuk khuluk). Dalam aspek ini UIDHR mengatakan bahwa setiap orang berhak untuk menikah (Pasal XIX ayat $1 / a)$, memilih istri/suami sesuai dengan keinginannya tanpa paksaan (ayat 2/b dan 9/i), membimbing anak dan keluarganya sesuai dengan agama, tradisi dan kebudayaannya (ayat 1), dan memperoleh dukungan material (seperti uang atau pekerjaan) untuk memenuhi kebutuhan hidup keluarganya (ayat 6). Disamping itu, suami wajib membiayai atau mencari nafkah untuk mempertahankan kehidupan anak dan istrinya (ayat 3).

Adapun istri memiliki hak untuk tinggal di rumah suaminya (Pasal XX ayat 1), menerima kebutuhankebutuhan yang penting demi kelangsungan hidupnya yang tidak melebihi kemampuan suaminya. Semasa cerai (masa idah) istri juga berhak menerima nafkah, berusaha dan memiliki harta yang sejak semula menjadi miliknya (ayat 2).

Istri juga mempunyai hak khuluk sesuai dengan hukum yang diajukan melalui proses pengadilan dan istri harus menunjukkan bukti-bukti kesalahan suami secara menyakinkan (daapat dipertanggungjawabkan) bahwa suaminya benar-benar melakukan kesalahan. Demikian juga istri yang dicerai, suami harus menunjukkan bukti-bukti kesalahan dan alasan cerai yang jelas (ayat 3 dan 5).

Kedua, waris. Dalam masalah waris UIDHR tidak menyebutnya secara panjang lebar/detail siapa saja yang dapat mewarisi harta ayah atau ibu yang meninggal (siapa yang menjadi ahli waris) dan berapa bagian masing-masing, siapa yang menjadi ahli waris ashabah, Aul, Radd dan konsep-konsep waris lainnya seperti yang ada didalam kitab-kitab fikih. UIDHR hanya menyatakan bahwa; istri mempunyai hak waris terhadap suaminya yang meninggal, terhadap ayahnya,

${ }^{28}$ Pasal-pasal ini dikutip dari Tahir Mahmood, Human Rights in Islamic Law, h. 161-174. Agar tidak terdapat kekeliruan dalam peninjauan kembali pasal-pasal ini perlu dijelaskan bahwa Tahir Mahmood tidak mencantumkan pasal XVII pada h. 171. anaknya dan keluarga-keluarga lainnya sesuai dengan hukum (Pasal XX ayat 4).

Ketiga, hadanah. Sebenarnya menurut konsep fikih klasik bahwa hadanah berkenaan dengan hak memelihara anak setelah terjadi perceraian antara suami dan istri. Akan tetapi yang penulis maksudkan di sini adalah tentang hak-hak yang wajib diterima anak dari orang tuanya.

Pasal-pasal UIDHR menjelaskan bahwa seorang ayah wajib memberi nafkah pada istri dan anaknya sesuai dengan kemampuannya (Pasal XIX ayat 3). Dilihat dari pasal ini bahwa anak berhak untuk diberi nafkah oleh ayahnya bukan ibunya. Namun, jika orang tuanya (parents=baik bapak atau ibu, pen) tidak mampu memberi nafkah karena keadaan tertentu (misalnya karena miskin), maka hak nafkah anak ditanggung oleh negara (misalnya anak dapat ditampung di Panti Asuhan, Indonesia).

Disamping itu, anak berhak mendapatkan dukungan materi (benda-benda materi lainnya), perhatian dan perlindungan dari orang tuanya semasa kecilnya atau ketika masa dewasa tetapi anak masih belum mempunyai rusd (kecerdasan yang menjadi kapasitas untuk berbuat) (Pasal XIX ayat [6]). Anak juga tidak boleh dipaksa bekerja pada usia yang relatif sangat muda atau walaupun berumur tetapi ia tidak mampu ditakutkan akan membahayakan pertumbuhan mereka (ayat [4]). Anak juga berhak mendapatkan pendidikan sesuai dengan kemampuannya (Pasal XIX ayat [1]) dan bahkan menuntut ilmu ini adalah kewajiban setiap orang Islam (Pasal XII ayat [2])

\section{Perbandingan Hak Nikah, Nafkah, Hadanah, dan Waris UDHR dan UIDHR}

Setelah mengurai aspek-aspek hukum keluarga yang terdapat dalam HAM Internasional (UDHR) dan HAM Islam (UIDHR), maka dapat dibandingkan keduanya dengan melihat titik-titik perbedaan dan persamaannya dalam masalah-masalah yang disentuh.

Pertama, masalah nikah dan nafkah. Dalam hal nikah UDHR menyebutkan pernikahan yang dilakukan antara pria dan wanita adalah bebas sebebas-bebasnya tanpa memandang unsur-unsur agama, negara atau kebangsaan (Pasal 16 ayat [1]). Berbeda dalam HAM Islam (UIDHR) yang menjelaskan bahwa pernikahan yang dilakukan juga menjadi hak setiap orang dan suami atau istri berhak membimbing/mendidik anaknya tetapi harus sesuai dengan agama yang dianutnya, budaya dan tradisi lingkungan yang ia miliki. (Pasal XIX ayat [1/a]). 
Pasal ini secara tekstual mensyaratkan perkawinan yang dilakukan harus sesuai dengan agama. Ann Elizabeth Mayer berpendapat bahwa UIDHR memberi implikasi bahwa seseorang yang ingin menikah harus menaati syariat atau perintah agamanya. Akibatnya seorang pria Muslim tidak boleh menikahi wanita yang non-Islam dan demikian juga sebaliknya. ${ }^{29} \mathrm{Hal}$ ini sama saja seperti yang dikemukakan oleh kitabkitab fikih yang ada. Dengan demikian, secara implisit pasal ini juga membolehkan pria menikahi wanita abl al-kitâb dan membawanya ke dalam agama Islam beserta anaknya, dan dalam hal ini penulis berbeda dengan pendapat Mayer yang menyatakan tidak boleh mengawini ahl al-kitâb. ${ }^{30}$

Di samping itu baik HAM Internasional (UDHR) maupun HAM Islam (UIDHR), sama-sama mensyaratkan perkawinan harus dilakukan secara suka rela atau berdasarkan atas suka sama suka (UDHR, pasal 16 ayat 2 dan UIDHR pasal XIX ayat 9). Sebagai tambahan, dalam UIDHR suami diwajibkan (obliged) memberi nafkah istri dan anaknya (pasal XIX ayat 3) sedangkan dalam UDHR tidak menyebutkan kewajiban itu. UDHR hanya menyebutkan bahwa setiap orang berhak atas upah dari kerjanya untuk menjamin kehidupan keluarganya (pasal 23 ayat 3), berhak atas tingkat penghidupan yang menjamin kesehatan dan keadaan baik bagi diri dan keluarganya (pasal 25 ayat 1) dan istri berhak mendapat perawatan dan perlakuan istimewa (pasal 25 ayat 2).

Pasal yang terakhir juga ini tidak menjelaskan bahwa perawatan dan perlakuan istimewa itu harus diperoleh dari suami (kewajiban suami), tetapi lebih bersifat umum. Akibatnya, dapat dipahami bahwa ibu-ibu baik yang sedang hamil atau tidak, beserta anaknya berhak memperoleh perawatan dan perlakuan yang istimewa dari rumah sakit, pemerintah atau institusi-institusi sosial lainnya.

Kedua, masalah waris. Adapun dalam masalah waris UDHR tidak menyebutkan sama sekali karena HAM ini tidaklah didasarkan pada hukum Islam yang megatur tentang waris. Namun yang jelas UDHR menyebutkan bahwa setiap orang berhak memiliki (mempunyai hak milik), baik milik sendiri ataupun milik bersama-sama dengan orang lain yang tidak boleh dirampas oleh orang lain (pasal 17 ayat 1 dan 2). Sebab terjadinya pemilikan tidaklah disebut dalam UDHR apakah berasal dari warisan atau hasil usaha sendiri atau hasil usaha bersama dengan orang lain.

${ }^{29}$ Ann Elizabeth Mayer, Islam And Human Rights, Edit. II (London: Pinter Publisher, t.th), h. 102

${ }^{30}$ Ann Elizabeth Mayer, Islam And Human Rights, h. 102.
Berbeda dengan HAM Islam (UIDHR), meskipun tidak detail, menyebutkan bahwa seorang istri mempunyai hak untuk mewarisi harta benda yang ditinggalkan suaminya yang meninggal, orang tuanya, anaknya atau bahkan keluarganya yang lain sesuai dengan hukum (pasal XX ayat 4). Adapun pembagiannya atau besar jumlah bagian istri dan siapasiapa saja yang mewarisi lainnya tidaklah disebutkan baik oleh UDHR atau UIDHR secara jelas dan rinci. Hal ini, menurut UIDHR, harus diatur dengan hukum Islam yang berlaku di negara-negara Muslim yang menganut mazhab-mazhab yang berbeda.

Namun, jika kita pahami dari UDHR Pasal 16 ayat (1) yang menyatakan bahwa suami (laki-laki) dan istri (perempuan) memiliki hak yang sama baik pada waktu sebelum nikah, sesudah nikah atau setelah terjadi perceraian (misalnya cerai mati), maka hal ini mengindikasikan bahwa suami istri memperoleh bagian harta warisan yang sama. Berbeda dengan UIDHR, hak-hak itu diatur sesuai dengan hukum (law) yang dalam hal ini shari'a, kata Mayer. ${ }^{31}$

Demikian juga seperi yang dijelaskan pada pasal XIX ayat 8 , hak-hak suami istri disesuaikan dengan jenis kelamin mereka. Ini dapat berarti bahwa perempuan mendapat $1 / 2$ dari laki-laki sesuai dengan peraturan fikih klasik yang ada. Adapun masalah bahagian anak, bapak, ibu dan seterusnya serta konsep-konsep waris lainnya seperti Awl, Radd, dan Ashâbah tidak dijelaskan secara gamblang.

Ada baiknya memang, hal itu tidak diatur, karena pembagian harta warisan secara detail dan penerapan konsep-konsep waris lainnya (seperti $A w l$ dan Radd), tidaklah harus dipaksakan pada setiap negara Islam atau negara-negara yang penduduknya mayoritas Islam untuk melaksanakannya. Tetapi hal ini disesuaikan dengan keadaan, kondisi dan mazhab-mazhab yang dianut oleh masayarakat Islam setempat. Seandainya semuanya diatur secara detail, maka hilanglah nilai keuniversalan HAM Islam itu sendiri.

Ketiga, hadanah dan pendidikan anak. Pada hakikatnya kedua HAM yang ada memberikan hak kepada setiap orang (anak) untuk memperoleh pendidikan, meskipun terdapa sedikit pernyataan yang berbeda. HAM Internasional (UDHR) misalnya mengatakan bahwa setiap orang berhak mendapat pengajaran. Pengajaran itu harus cuma-cuma, setidaknya pada tingkat sekolah rendah dan dasar dan sekolah dasar harus diwajibkan (pasal 26 ayat 1). Ibu bapak adalah orang yang paling berhak memilih pendidikan anaknya

\footnotetext{
${ }^{31}$ Ann Elizabeth Mayer, Islam And Human Rights, h. 103
} 
(ayat [3]) dan mereka tidak boleh diganggu dengan sewenang-wenang dalam urusan keluarga dan rumah tangganya (Pasal [12]).

Sedikit berbeda degan peraturan yang ditetapkan oleh HAM Islam (UIDHR), hal-hal yang diatur adalah bahwa anak (setiap orang) berhak mendapatkan pendidikan sesuai dengan kemampuannya (Pasal XX ayat [1]), bukan wajib menerima pendidikan dasar seperti pada UDHR, dan orang tuanya berhak untuk membimbing anaknya kepada agama yang dianutnya (Pasal XIX ayat [1]). Di samping itu, orang tua tidak boleh memaksa anaknya untuk bekerja keras pada usia dini sehingga membahayakan perkembangan anak itu (ayat [4]).

Dengan demikian dalam HAM internasional pendidikan dasar adalah hak yang wajib diterima anak dan harus diperoleh secara cuma-cuma, sedangkan dalam HAM Islam tingkat pendidikan itu diserahkan sepenuhnya kepada kemampuan anak. Di samping itu HAM Islam tidak membolehkan orang tua memaksa anaknya dalam usia dini bekerja keras sedangkan dalam HAM Internasional hal ini tidak diatur akan tetapi anak hanya berhak mendapat perawatan dan bantuan istimewa seperti yang disebutkan diatas.

HAM Internasional (UDHR) juga menyerahkan kepada orang tua memilih pendidikan untuk anaknya sedangkan HAM Islam (UIDHR) menyerahkan kepada orang tua untuk menentukan agama apa yang harus dianut anak dan membimbingnya sesuai dengan agamanya itu (UDHR Pasal 26 ayat (3) dan UIDHR Pasal XIX ayat [1]).

\section{Penutup}

Setelah meneliti pasal-pasal yang ada pada kedua HAM di atas, baik HAM internasional dan HAM Islam, maka penulis mengambil simpulan tentang perbedaan dan persamaan kedua HAM ini dalam kaitannya dengan hukum keluarga. Pertama, dalam hal nikah UDHR memberikan kebebasan penuh tanpa memandang unsur-unsur agama, negara atau kebangsaan (Pasal 16 ayat [1]) sedangkan dalam HAM Islam (UIDHR) Pasal XIX ayat (1/a) terdapat isyarat bahwa pernikahan harus sesuai dengan ajaran agama sang mempelai.

Kedua, persamaan HAM Internasional (UDHR) dengan HAM Islam (UIDHR) adalah syarat perkawinan harus dilakukan secara suka rela atau berdasarkan atas suka sama suka (UDHR, Pasal 16 ayat (2) dan UIDHR Pasal XIX ayat [9]).

Ketiga, dalam UIDHR suami diwajibkan (obliged) memberi nafkah istri dan anaknya (Pasal XIX ayat [3]) sedangkan dalam UDHR tidak menyebutkan kewajiban itu sama sekali. UDHR hanya menyebutkan semua orang berhak mendapat upah kerja untuk hidup layak (Pasal 23 ayat [3]).

Keempat, dalam masalah waris UDHR tidak menyebutkan sama sekali, berbeda dengan HAM Islam (UIDHR) menyebutkan bahwa seorang istri mempunyai hak untuk mewarisi harta benda yang ditinggalkan suaminya yang meninggal, orang tuanya, anaknya atau bahkan keluarganya yang lain sesuai dengan hukum (Pasal XX ayat [4]).

Kelima, dalam hal hadanah, HAM Internasional hanya memberikan hak pada setiap anak untuk mendapatkan pendidikan sekolah rendah dan dasar (Pasal 26 ayat [1]) dan Ibu bapaknya berhak memilih jenis pendidikan anaknya (ayat [3]) dan mereka tidak boleh diganggu dalam urusan keluarga dan rumah tangganya (Pasal [12]). Sedikit berbeda dengan HAM Islam (UIDHR) bahwa anak (setiap orang) berhak mendapatkan pendidikan sesuai dengan kemampuannya (Pasal XX ayat [1]), dan orang tuanya berhak untuk membimbing anaknya kepada agama yang dianutnya (Pasal XIX ayat [1]). Di samping itu orang tua tidak boleh memaksa anaknya untuk bekerja keras pada usia dini sehingga membahayakan perkembangan anak itu (ayat [4]).

Demikian beberapa perbedaan dan persamaan penting yang terdapat dalam HAM Internasional dan HAM Islam dalam kaitannya dengan hukum keluarga. Hal tersebut memperlihatkan kelebihan HAM Islam dari HAM Internasional dan lebih sesuai dengan nilainilai universal Islam itu sendiri. []

\section{Pustaka Acuan}

Cassesse, Antonio, Hak Asasi Manusia di Dunia yang Berubah, diterjemahkan oleh A. Rahman Zainuddin, Jakarta: Yayasan Obor Indonesia, 1994.

Farsythe, David. P, Hak-hak Asasi Manusia dan Politik Dunia, diterjemahkan oleh Tom Gunadi, Bandung: Angkasa, 1993.

Hussein, Syafukat, Hak Asasi Manusia dalam Islam, Jakarta: Gema Insani Press, 1996.

Kamil, Sukron dkk., Syariah Islam dan HAM, Cet. 1 Jakarta : CSRC, 2007.

Maudhudi, Abul A'ala, Hak-Hak Asasi Manusia dalam Islam, diterjemahkan oleh Bambang Iriana Djajaatmaja, Jakarta: Bumi Aksara, 1995.

Mayer, Ann Alizabeth, Islam And Human Rights, Edit. II, London: Pinter Publisher, t.th.

Muzaffar, Candra, Hak Asasi Manusia dalam Tata Dunia 
Baru, diterjemahkan oleh Poerwanto, Bandung: Mizan, 1995.

Nasution, Harun dan Bahtiar Effendi (ed.), Hak Azasi Manusia dalam Islam, Jakarta: Yayasan Obor Indonesia, 1987.

Peter Davis, Peter, Hak-Hak Asasi Manusia: Sebuah Bunga Rampai, diterjemahkan oleh A. Rahman Zainuddin, Jakarta: Yayasan Obor Indonesia, 1994.
Shaukat, Parveen, Human Rights In Islam, India: Adam Publisher \& Distributors, 1995.

Tahir Mahmud, Tahir, Human Rights In Islamic Law, Edit.1, New Delhi: Institute of Objective Studies, 1993.

Wafi, Ali Abdul Wafi, Prinsip Hak Asasi dalam Islam, diterjemahkan oleh Abu Ahmad Al-Wakidi, Solo: Pustaka Mantiq, 1991. 